\author{
Cadernos de \\ ESTUDOS LINGUÍSTICOS - (58.1), Campinas, pp. 139-151 - jan./abr. 2016
}

\title{
THE VARIATION OF POST-VOWEL -S IN THE PORTUGUESE DIALECT OF RIO DE JANEIRO
}

\author{
EDVAN PEREIRA DE BRITO*
}

\begin{abstract}
"[He] used to speak fast, but articulating the words well and hissing all the ss, with a nice Carioca accent."

Rodrigo de Andrade, Velórios, 1936 (Quoted in Nascentes, 1953, p. 52)
\end{abstract}

\begin{abstract}
RESUMO: A cidade do Rio de Janeiro é conhecida por sua beleza exuberante e sua cultura única. Pelo menos entre os brasileiros, a cidade também se destaca por suas características dialetais, das quais a realização alveopalatal do - s pós-vocálico é provavelmente a mais notável. No dialeto carioca, $-\mathrm{s}$ pós-vocálico é geralmente pronunciado como os sons alveopalatais [J] e [3], diferente das pronúncias alveolares [s] e [z], mais comuns em alguns outros dialetos do português brasileiro. Em vista disso, o objetivo do presente estudo foi analisar a variação de - s pós-vocálico no referido dialeto para saber quais são os fatores linguísticos e sociais mais relevantes para a ocorrência desse fenômeno de variação. Seguindo os princípios da sociolinguística variacionista, foi analisada a influência de duas variáveis linguísticas - idade e gênero - e duas variáveis não-linguísticas - contexto sonoro seguinte e tipo silábico. Depois da análise dos dados com o VABRUL, constatou-se que tipo silábico e idade foram os grupos de fatores com influência mais significativa para a ocorrência de [J] e [3]. Contexto sonoro seguinte e gênero foram descartados como insignificantes.

Palavras-chave: palatalização; variação linguística; Rio de Janeiro.
\end{abstract}

RESUMEN: La ciudad de Río de Janeiro es conocida por su belleza exuberante y su cultura singular. Además, entre los brasileños la ciudad también se distingue por sus características dialectales, de las cuales la realización alveopalatal - $\mathrm{s}$ después de la vocal, en general, suena como los sonidos alveopalatales [ [] y [3], diferentemente de las pronunciaciones alveolares $[\mathrm{s}]$ e $[\mathrm{z}]$, más comunes en otros dialectos del portugués brasileño. Así, el reto de este estudio fue analizar la variación del -s después de la vocal en el referido dialecto para investigar cuales son los factores lingüísticos y sociales más importantes para la ocurrencia de ese fenómeno de la variación. A partir de los principios de la sociolingüística de la variación, se analizó la influencia de dos variables lingüísticas: edad y género - y dos variables no lingüísticas - contexto sonoro siguiente y tipo silábico. Después del análisis de los datos con el VABRUL, se evidenciaron que tipo silábico y edad fueron los grupos de factores con una influencia más significativa para la ocurrencia de $\left[\int\right]$ y [3]. Contexto del sonido después de la vocal y género fueron desechados como insignificantes.

Palabras-llaves: palatalización; variación lingüística; Rio de Janeiro.

* Doutorando no Programa de Doutorado em Sociolinguísitca da Georgetown University e Professor de Português como Língua Estrangeira na Howard University, ambas em Washington, DC, USA. Mestre em Comunicação pela Howard University. Bacharel e Licenciado em Letras (Português e Linguística) pela Universidade de São Paulo.epb26@georgetown.edu 


\section{INTRODUCTION}

Brazil's most notable characteristic is probably its diversity, which is expressed in all aspects of life, including language. Even though it is estimated that there are over 200 languages spoken in Brazil, Portuguese is the country's only official language. Yet, among all the regional dialects, the Portuguese spoken in the city of Rio de Janeiro or the Carioca dialect, is certainly the most known in the country because of its social and historical influence, which goes back to the colonial period, when the city was the capital for nearly two centuries. Moreover, most of the television networks broadcast from Rio de Janeiro and they generally produce telenovelas or soap-operas which also contribute to the expansion of aspects of the Carioca culture, including the dialect representative of it.

Most Brazilians would also agree with the idea that Rio de Janeiro is Brazil's Hollywood. As Guy (1981, p. 45) states,

\footnotetext{
the Carioca dialect is widely considered to be the national prestige dialect. Radio and television broadcasters, for example, predominantly use Carioca pronunciations. As a national center for broadcasting, publishing, and communications, Rio's norms are widely disseminated through the media.
}

Even though there are six possible phonetic realizations for post-vowel $-\mathrm{S}$ in the dialect of Rio de Janeiro, namely [S], [3], [s], [z], [h], and null, the postalveolar fricatives [S] and [3] are often taken as its most recognizable linguistic trait. Examples of these phonetic realizations are as follows:

1) Voiceless post-alveolar fricative [J]:

['treIf 'kơahtof]

$$
\begin{aligned}
& \text { três quartos } \\
& \text { three bedroom-[PL] } \\
& \text { 'three bedrooms' }
\end{aligned}
$$

2) Voiced post-alveolar fricative [3]:

[de' poIz 'da ko'zĩna]

depois da cozinha

after of + the kitchen

'after the kitchen'

3) Voiceless alveolar fricative [s]:

['kuahtu 'dzi 'ospıdzI]

quarto de hóspede

bedroom of guest

'guest bedroom'

4) Voiced alveolar fricative [z]:

[e $\int$ 'taduz u' niduf]

Estados Unidos

State-[PL] Unite-[PL]

'United States'

5) Voiceless glottal fricative [h]:

['mehmo]

mesmo

same

'same' 
Cadernos de ESTUDOS LINGUÍSTICOS (58.1) - jan./abr. 2016

6) Ø (null or -s deletion)

[if'tãmoØ akoftu' mados 'kõ 'isv]

estamos acostumados com isso
(we) are used to this
'we are used to this'

As mentioned above, post-vocalic -s is usually pronounced as the post-alveolar sounds [S] and [3] and they are considered a characteristic feature of the speech of Rio de Janeiro, as opposed to the alveolar pronunciations ([s], [z]), which are more common in some other dialects of Brazilian Portuguese. With this in mind, the objective of the present study was to analyze the variation of post-vocalic $-\mathrm{s}$ and to find out what linguistic and social factors are the most significant for the occurrence of [S] and [3], which characterize the Carioca dialect.

Aiming at answering this question, I analyzed the influence of two linguistic variables (following sound and syllable type) and two nonlinguistic variables (age group and gender) to the variation of post-vowel $-\mathrm{s}$ in the dialect of Rio de Janeiro. The 600 tokens that compose the data were collected from twelve interviews, which are part of the Project of Standard Urban Speech of Rio de Janeiro - NURC Project ${ }^{1}$ [Projeto da Norma Urbana Oral Culta do Rio de Janeiro]. After using VARBRUL to analyze the data, I found that syllable type and age were the factor groups with the most significant influence for the occurrence of [S] and [3]. Following sound and gender were both discarded as insignificant. In what follows, I provide more detailed information about the variation of $-\mathrm{s}$ in Brazilian Portuguese in general, and in the dialect of Rio de Janeiro in particular, along with a review of previous studies. This section is followed by the methodology, in which I present more specific explanation about the research design of the study. In the analysis and discussion section, I provide my findings and discuss some of their implications to the variation phenomenon in question. The last section of the paper is dedicated to my final considerations about the study.

\section{POST-VOWEL -S IN BRAZILIAN PORTUGUESE}

Sociolinguistic variation is certainly one the most expressive elements of the existing cultural diversity in Brazil as in any other country with such geographic proportions. The map below is one of the most recent attempts to describe isoglosses in dialectal zones in Brazil.

\footnotetext{
${ }^{1}$ For more information on The NURC Project go to http://www.letras.ufrj.br/nurc-rj/
} 


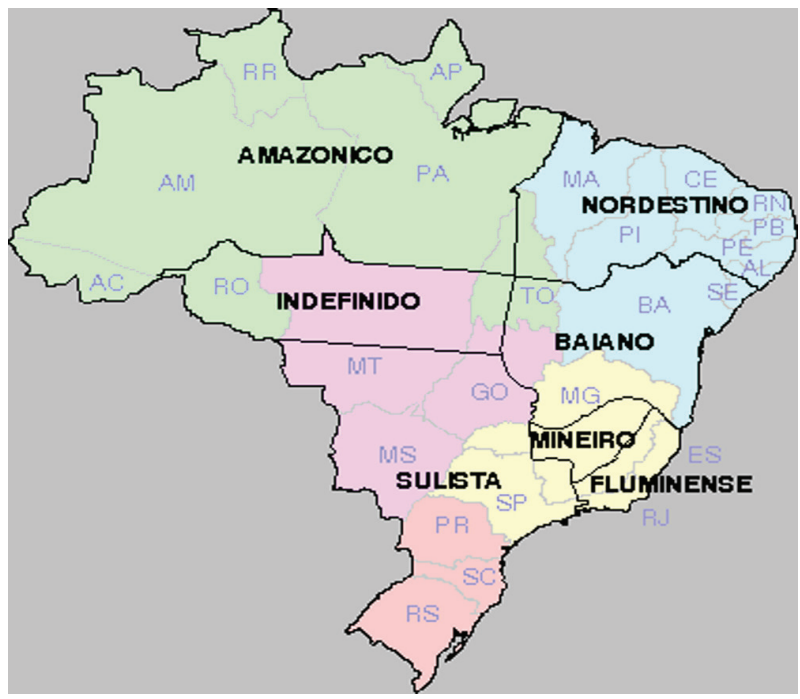

Figure 1: Brazilian dialectal zones².

According to the map, Brazil would have seven dialectal zones. However, even though the map illustrates most of the differences and similarities among dialects, it does not do a good job in terms of representing very distinct dialects, such as those spoken throughout the coast and in the interior of the states, especially in the northeastern region.

As far as phonological variation is concerned, the variation of $-\mathrm{s}$ in wordand syllable-final positions seems to be one of the most recurring across dialects and within the same dialect in Brazilian Portuguese. Although also present in other dialects, the variation of the sibilant in word- or syllable-final positions is a characteristic feature of the dialect spoken in the city of Rio de Janeiro. As it has been described by some grammar manuals of the Portuguese language and other studies (Ackerlind; Jones-Kellogg 2011; Guy 1981; Lopez 1979; Perini 2002; Silva 1998), the distribution of the variants of post-vocalic -s in Brazilian Portuguese is characterized by the following rules:

1. It occurs as [s] or [J] in syllable-final position followed by a voiceless consonant or in word-final position. For example, the word história 'history' can be pronounced as [is' toria] or [IS' torıa].

2. It occurs as [z] or [3] in syllable-final position followed by voiced consonant. One example would be the word asma 'asthma', which can be pronounced either as ['azma] or ['azma].

3. It is realized as [z] in any dialect when it occurs in between two vowels, as in as armas 'the guns', which is always pronounced as ['az 'ahmas] or ['az 'ahmaf].

\footnotetext{
${ }^{2}$ Source: http://www.cin.ufpe.br/ rac2/portugues/dialebr.html
} 
Cadernos de ESTUDOS LINGUISTIICOS (58.1) - jan./abr. 2016

As we can see, the sounds [s], [z], [J], and [3] are neutralized in syllable-final position in Portuguese and as so most scholars would argue that they should be represented with the archiphoneme $/ \mathrm{S} /$. In other words, the opposition that occurs among these phonemes in other contexts disappears in syllable-final position in Portuguese. In addition to these realizations, in the dialect of Rio de Janeiro post-vowel $-\mathrm{s}$ can also be realized as $[\mathrm{h}]$ and [ø], which are also loaded with a certain degree of stigma for being more characteristically associated with lower social classes and lower levels of educational.

A considerable number of studies have looked at the variation of post-vocalic $-\mathrm{s}$ in some dialects of Portuguese using a sociolinguistic framework, but I will only discuss the ones that focused on Rio de Janeiro. One of these first empirical studies was done by Reis (1992), who interviewed twelve participants in Rio de Janeiro and analyzed the retraction of the sibilant $[\mathrm{s}]$ and $[\mathrm{z}]$ in relation to the social characteristics of the participants. Based on Labov's (1972) study, Reis used three different strategies to elicit the tokens of the variable he was analyzing. Thus, informants were asked to read a vocabulary list and a text, and finally to engage in free conversation. These three stages would represent a continuum from less casual to more casual speech. Reis found that retraction or palatalization was more prevalent in the more casual speech. Female speakers used retraction of the sibilants [s] and [z] more than males, even though the difference between the two groups was not significant. Retraction was also more frequent among the younger speakers ages 18-25. Reis' study is important because it sheds light on some of the possible social factors that seem to be more significant for the occurrence of the palatalization of $-\mathrm{s}$ in the Portuguese spoken in Rio de Janeiro.

In another sociolinguistic study conducted by Scherre and Macedo (2000), ${ }^{3}$ they approached the variation of post-vocalic $-\mathrm{s}$ in Rio de Janeiro by looking at its phonetic, phonologic, and lexical restrictions. These restrictions were measured in terms of (1) following sound, (2) preceding vowel, (3) position of $-\mathrm{s}$, number of syllables, and stress, and (4) lexical category and specific lexical items. Despite the importance of all of theses variables, only the first and third ones will be considered for the purpose of the present study. Overall, Scherre and Macedo found that both palatal and alveolar variants were favored by the occurrence of pause as well as voiceless consonants in the following environment. The glottal and null variants, on the other hand, were more favored by the occurrence of voiced consonants. Considering the third factor group, namely position of $-\mathrm{s}$, number of syllables, and stress, Scherre and Macedo report that when -s occurs in word-final position it favors the occurrence of [h] or $-\mathrm{s}$ deletion, as opposed to mid-word position, which would favor palatalization. As explained by the authors, the presence of $[\mathrm{h}]$ and $-\mathrm{s}$ deletion in mid-word position is restricted in Portuguese because this would lead to a change in meaning. One example of such restriction would be the words pasto 'pasture', parto 'child-birth', and pato 'duck', which are respectively pronounced as ['pafto], ['pahto], and ['pato]. The system would then prevent the variants [h] and null to appear in the middle of a word even when the alternation would not result in a change in meaning. In the case of stress, the authors found that stressed syllables containing

\footnotetext{
${ }^{3}$ The original study is from 1996.
} 
$-\mathrm{s}$ in mid-word position would favor the occurrence of palatalization more than unstressed ones, whereas when -s occurs in stressed syllables in word-final position, this would favor the appearance of [h]. Based on these findings alone, it is hard to determine the extent to which stress plays a role for the occurrence of these variants because this feature is analyzed in combination with other factors. Even so, Scherre and Macedo's results provide a comprehensive picture of the linguistic factors that condition the variation of post-vocalic $-\mathrm{s}$ in the Carioca dialect.

In conclusion, the studies just described provide very clarifying insights about the relationship between the variation of $-\mathrm{s}$ in the Carioca dialect and its influencing linguistic and social factors. In trying to describe the linguistic and social conditioning factors of post-vowel $-\mathrm{s}$ variation in the Portuguese spoken in Rio de Janeiro using sociolinguistic interviews recorded in the 1970's, I intend to compare the results of the study with those of Reis and Scherre and Macedo to see whether there is any evidence of change in progress for the variation in question. My hypothesis is that the patterns that the findings reported in these studies were already ocurring in the 1970s. Even though the present study is by no means a replication of these two studies, it is significant because it can provide evidence of change in progress in terms of -s palatalization not only in the Carioca dialect, but also in other dialects where such a pattern has been observed. In trying to accomplish this objective, many methodological aspects were taken into consideration and I discuss those in the next section.

\section{METHODOLOGY}

The data for the present study were collected from the Project of Standard Urban Speech of Rio de Janeiro or Projeto da Norma Urbana Oral Culta do Rio de Janeiro (NURC), which provides a large amount of data, including audio files and transcriptions, for linguistic analysis free of charge for any person with access to the Internet. The NURC Project is composed of sociolinguistic interviews made in the 1970s and 1990s. There are a larger number of interviews from the first decade compared to those of the 1990s. The newer set of recordings is actually interviews with the same interviewees of the 1970s. As for demographic information of the people interviewed for the project, all of them were born in the city of Rio de Janeiro, Brazil, as were most of their parents. In addition, all participants also had a college degree at the time of the interview. The interviews of the 1970s are gathered in three age groups: 25-35 years old, 35-55 years old, and 56 years old and older; the interviews from the 1990s are grouped as: 35-55 years old, 56-73 years old, and 74-80 years old.

Using Transcriber, I collected 50 tokens from each of the twelve interviews used for this research. These data were from the 1970s interviews, for which I tried to select an equal number of tokens to represent the different gender and age groups. I collected an initial corpus consisting of 600 tokens of the six ([J], [3], $[\mathrm{s}],[\mathrm{z}],[\mathrm{h}]$, and null) different realizations of post-vowel $-\mathrm{s}$ in the Carioca dialect. Five was the maximum number of tokens of the same word produced by speaker accepted in the data. Table 1 below gives an overview of the original data collected for analysis. 
Table 1: Overall information of the data used for analysis

\begin{tabular}{|c|c|c|c|c|}
\hline Gender/Age & $25 / 35$ & $35-55$ & 56 -older & Total \\
\hline Male & 100 & 100 & 100 & 300 \\
\hline Female & 100 & 100 & 100 & 300 \\
\hline Total & 200 & 200 & 200 & 600 \\
\hline
\end{tabular}

Four independent variables or factor groups were considered for analysis in addition to the dependent variable $-\mathrm{s}$. Thus, each token was coded for syllable type (stressed or unstressed), following sound (consonant, vowel, or pause), gender (male or female), and age group (25-35, 36-55, or 56 and older), and $-\mathrm{s}$ realization ([ᄃ], [3], [s], [z], [h], and null). Examples of these realizations are reproduced below:

1) Voiceless post-alveolar fricative [S]:

['tres』 'konahtof]

três quartos

three bedroom-[PL]

'three bedrooms'

2) Voiced post-alveolar fricative [3]:

[de' poIz 'da ko'zĩna]

depois da cozinha

after of +the kitchen

'after the kitchen'

3) Voiceless alveolar fricative [s]:

['kuahtu 'dzi 'ospıdzI]

quarto de hóspede

bedroom of guest

'guest bedroom'

4) Voiced alveolar fricative $[z]$ :

[e $\int^{\prime}$ taduz u' niduf]

Estados Unidos

State-[PL] Unite-[PL]

'United States'

5) Voiceless glottal fricative [h]:

['mehmo]

mesmo

same

'same'

6) Ø (null or -s deletion)

[if'tãmoØ akoftu'madof 'kõ 'isv] estamos acostumados com isso

(we) are used to this

'we are used to this'

Table 2 gives more detailed information about the factor groups considered for analysis and their respective variants. 
Table 2: Factor groups used for VARBRUL analysis

\begin{tabular}{|c|c|c|}
\hline FG \# & Factor Group & Variants \\
\hline \multirow{6}{*}{ Factor Group 1} & \multirow{6}{*}{-s realization } & {$\left[\int\right]$} \\
\hline & & [3] \\
\hline & & {$[\mathrm{s}]$} \\
\hline & & {$[\mathrm{z}]$} \\
\hline & & {$[\mathrm{h}]$} \\
\hline & & {$[\varnothing]$} \\
\hline \multirow{3}{*}{ Factor Group 2} & \multirow{3}{*}{ Following sound } & vowel \\
\hline & & consonant \\
\hline & & pause \\
\hline \multirow{2}{*}{ Factor Group 3} & \multirow{2}{*}{ Syllable type } & unstressed \\
\hline & & stressed \\
\hline \multirow{3}{*}{ Factor Group 4} & \multirow{3}{*}{ Age Group } & $25-35$ \\
\hline & & $36-55$ \\
\hline & & $56+$ \\
\hline \multirow{2}{*}{ Factor Group 5} & \multirow{2}{*}{ Gender } & male \\
\hline & & female \\
\hline
\end{tabular}

In the next section, I present the results of the VARBRUL analysis of the data just described as well as a discussion of how these results impacted my research goal.

\section{ANALYSIS AND DISCUSSION}

After compiling the data and determining the factor groups, the next step was to conduct a VARBRUL analysis in order to obtain a general picture of the variation phenomenon I was seeking to describe. For this first round of analysis, I had to combine the [h] and null variants so as not to exceed the number of factors per factor group, which is set in VARBRUL as five. Table 3 below presents the distribution of $-\mathrm{s}$ variation in relation to the linguistic and social factors. 
Cadernos de ESTUDOS LINGUISTTICOS (58.1) - jan./abr. 2016

Table 3: Overall distribution of post-vowel -s by linguistic and social factors (Preliminary results)

\begin{tabular}{|c|c|c|c|c|c|c|c|c|}
\hline & & & [J] & [3] & {$[\mathrm{z}]$} & [s] & {$[\mathrm{h}]+$ null } & Total \\
\hline \multirow{6}{*}{ 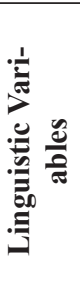 } & \multirow{3}{*}{$\begin{array}{c}\text { Following } \\
\text { Sound }\end{array}$} & Vowel & 0 & 0 & 112 & 0 & 2 & $114(19 \%)$ \\
\hline & & Consonant & 225 & 100 & 10 & 33 & 13 & $381(63.5 \%)$ \\
\hline & & Pause & 90 & 2 & 1 & 12 & 0 & $105(17.5 \%)$ \\
\hline & & & & & & & & \\
\hline & \multirow{2}{*}{$\begin{array}{c}\text { Syllable } \\
\text { Type }\end{array}$} & Unstressed & 225 & 64 & 78 & 31 & 5 & $403(67.2 \%)$ \\
\hline & & Stressed & 90 & 38 & 45 & 14 & 10 & $197(32.8 \%)$ \\
\hline & & & & & & & & \\
\hline \multirow{7}{*}{ 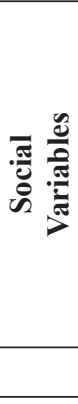 } & \multirow{3}{*}{$\begin{array}{l}\text { Age } \\
\text { Group }\end{array}$} & $25-35$ & 119 & 36 & 31 & 9 & 5 & $200(33.3 \%)$ \\
\hline & & $36-55$ & 94 & 31 & 56 & 12 & 7 & $200(33.3 \%)$ \\
\hline & & 56-older & 102 & 35 & 36 & 24 & 3 & $200(33.3 \%)$ \\
\hline & & & & & & & & \\
\hline & \multirow{2}{*}{ Gender } & Male & 171 & 45 & 49 & 30 & 5 & $300(50 \%)$ \\
\hline & & Female & 144 & 57 & 74 & 15 & 10 & $300(50 \%)$ \\
\hline & Total & & 315 & 102 & 123 & 45 & 15 & 600 \\
\hline \multicolumn{2}{|c|}{ Percentage } & & $52.5 \%$ & $17 \%$ & $20.5 \%$ & $7.5 \%$ & 2.5 & $100 \%$ \\
\hline
\end{tabular}

These first results reveal very interesting aspects about the data. As expected, [S] was the most frequent $-\mathrm{s}$ variant with $315(52.5 \%)$ occurrences. The second and third most frequent variants were [z] and [3], with $123(20.5 \%)$ and $102(17 \%)$ occurrences, respectively. As expected, the data also show that when $-\mathrm{s}$ is followed by a vowel it is very likely that it will be realized as [z]. I will come back to this point later when I comment a little bit more about the influence of the linguistic factors. In addition, the [s] variant accounts for less than 10 percent of the $-\mathrm{s}$ realizations. In fact, in most dialects of Brazilian Portuguese, $-\mathrm{s}$ tends to be realized as [s] while in the Carioca dialect it is realized as [ $]$ ], which for most outsiders is probably the most prominent linguistic feature that characterizes this speech variety. The occurrence of $[\mathrm{h}]$ and null variants, which combined represent 2.5 percent (15 occurrences) of the $-\mathrm{s}$ realizations, was also expected even though these two variants are very stigmatized in the speech community. Although it is not shown in the results, [h] had ten occurrences, of which only one was produced by a male participant of the 36-55 age group. The two younger female groups (25-35 and 36-55) produced eight out of the ten occurrences of [h]. This is actually different from what Reis found in his study. Reporting on data collected in the 1990s, he speculates that the production of this variant seems to be associated with "a younger male speech style" (p. 51). Perhaps with a larger data set with both standard and vernacular speeches I would be able to confirm this. 
Another aspect of the data is that pause, in stressed and unstressed syllables, seems to influence the occurrence of [ $\left.\int\right]$. Moreover, as I pointed out earlier, when there is a vowel in the following environment, it is likely that $-\mathrm{s}$ will be invariably realized as $[z]$ in any dialect of Brazilian Portuguese. In other words, in this situation only $[\mathrm{z}]$ is expected to occur. The realization of these facts led me to make some methodological changes.

Since I wanted to see a more realistic representation of the data and to follow the methodology of previous studies (Reis 1992; Scherre; Macedo 2000), I decided to reformulate factor group 1. First, I decided to combine [S] and [3] into a factor called palatal. I also removed from the data all 114 cases in which $-\mathrm{s}$ was preceded by a vowel because in this context it is likely that it will be realized as [z]. The remaining cases of $[\mathrm{z}]$ (-s before consonant and pause) were grouped together with [s] to form the alveolar variant. The $[\mathrm{h}]$ and null variants remained together as the third factor in my analysis. The statistical results after making those changes are shown in table 4.

Table 4: Overall distribution of post-vowel $-\mathrm{s}$ variation in the Carioca dialect

\begin{tabular}{|c|c|c|c|c|c|}
\hline & $\begin{array}{c}{\left[\int\right]+[3]} \\
\text { Application }\end{array}$ & $\begin{array}{c}{[\mathrm{s}]+[\mathrm{h}]+\text { null }} \\
\text { Non-Application }\end{array}$ & Total \\
\hline \multirow{4}{*}{ 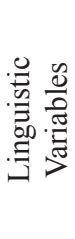 } & \multirow{2}{*}{$\begin{array}{l}\text { Following } \\
\text { Sound }\end{array}$} & Consonant & $325(85.3 \%)$ & $56(14.7 \%)$ & $381(78.4 \%)$ \\
\hline & & Pause & $92(87.6 \%)$ & $13(12.4 \%)$ & $105(21.6 \%)$ \\
\hline & \multirow{2}{*}{$\begin{array}{l}\text { Syllable } \\
\text { Type }\end{array}$} & Unstressed & $289(88.1 \%)$ & $39(11.9 \%)$ & $328(67.2 \%)$ \\
\hline & & Stressed & $128(81 \%)$ & $30(19 \%)$ & $158(32.8 \%)$ \\
\hline \multirow{6}{*}{ 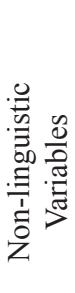 } & \multirow{3}{*}{$\begin{array}{l}\text { Age } \\
\text { Group }\end{array}$} & $25-35$ & $155(92.3 \%)$ & $13(7.7 \%)$ & $168(34.6 \%)$ \\
\hline & & $36-55$ & $125(81.2 \%)$ & $29(18.8 \%)$ & $154(31.7 \%)$ \\
\hline & & 56-older & $137(83.5 \%)$ & $27(16.5 \%)$ & $164(33.7 \%)$ \\
\hline & & & & & \\
\hline & \multirow{2}{*}{ Gender } & Male & $216(86.1 \%)$ & $35(13.9 \%)$ & $251(51.6 \%)$ \\
\hline & & Female & $201(85.5 \%)$ & $34(14.5 \%)$ & $235(48.4 \%)$ \\
\hline \multicolumn{2}{|r|}{ Total } & & $417(85.8 \%)$ & $69(14.2 \%)$ & $486(100 \%)$ \\
\hline
\end{tabular}

The above table presents statistical results obtained after grouping the most frequent variants of $-\mathrm{S}$ in the Carioca dialect. The results indicate that [ $\mathrm{S}]$ or [3] account for $85.3 \%$ of the occurrences compared to the other variants of $-\mathrm{s}$. A similar situation is perceived when $-\mathrm{s}$ is followed by a pause, in which case they account for $87.6 \%$ of total occurrences in that linguistic environment. Unstressed syllables seem to favor the occurrence of [S] and [3], accounting for $88.1 \%$ of the occurrences. In addition, the younger group (25-35) also seems to have a higher use of [ $]$ ] and [3] than the older speakers. A similar representation was also obtained when I compared the factor weights provided by the one level analysis and step-up/step-down analysis. Detailed results are shown in table 5 below. 
Table 5: Multivariate analyses of the contribution of internal and external factors selected as significant to the probability of occurrence of [S] and [3]; factor groups not selected as significant in square brackets

\begin{tabular}{|c|c|c|c|}
\hline & & & ca Dialect \\
\hline Corrected $\mathrm{m}$ & ability & & 0.87 \\
\hline Log likeliho & & & -191.636 \\
\hline Chi-square & & & 1.7619 \\
\hline Total Chi-sc & & & 42.2848 \\
\hline Total N & & & 438 \\
\hline & Factor Weight & $\%$ & $\mathrm{~N}$ \\
\hline Age group & & & \\
\hline $25-35$ & .65 & 92 & 168 \\
\hline $56+$ & .44 & 84 & 164 \\
\hline $36-55$ & .40 & 81 & 154 \\
\hline Syllable typ & & & \\
\hline Unstressed & .54 & 88 & 328 \\
\hline Stressed & .41 & 81 & 158 \\
\hline Following s & & & \\
\hline Pause & {$[.51]$} & 87 & 105 \\
\hline Consonant & [.49] & 85 & 381 \\
\hline Gender & & & \\
\hline Female & {$[.50]$} & 86 & 235 \\
\hline Male & [.49] & 86 & 251 \\
\hline
\end{tabular}

As shown above, the best runs in the step-up/step-down analysis were age group and syllable type. In other words, unlike following sound and gender, age group and syllable type significantly affect the occurrence of palatalization. Among the age groups, the younger group (25-35) had the higher level of palatalization (.65). This actually corroborates Reis' finding that younger speakers, tend to use [S] and [3] more than older speakers.

Additionally, in a study of post-vowel -s by Gryner and Macedo (2000) in the Cordeiro region of Rio de Janeiro state, where the variation between palatal and alveolar pronunciations is more balanced than in Rio de Janeiro city, the palatalization of $-\mathrm{s}$ is an innovative pattern and has been carried out also by the younger speakers. Older speakers would favor the alveolar pronunciation. In this sense, a possible explanation for the fact that palatalization decreases with age would be that, as the palatal variants are markedly associated with the linguistic identity of Rio de Janeiro, the younger groups are probably more strongly engaging in showing their ties to the community and their Carioca identity. Obviously, these claims have to be pursued by further investigations with a larger and more representative data set. 
In the case of syllable type, which also significantly affects palatalization, this study indicates a slight degree of correlation between unstressed syllable and the occurrence of [S] and [3] in the Carioca dialect (.54). In their study, Scherre and Macedo also found that lack of stress favored palatalization, especially when $-\mathrm{s}$ appeared in mid-word position. A possible explanation for the influence of this variant might be the fact that in Portuguese phonological variation is more likely to occur in unstressed syllables compared to stressed ones. Again, the study of a larger data set with the analysis of more linguistic factors would reinforce the claims being made here.

\section{FINAL CONSIDERATIONS}

In the present study I analyzed the variation of post-vocalic $-\mathrm{S}$ in the Portuguese dialect spoken in Rio de Janeiro. The main goal of the study was to discover the extent to which the two palatal variants [J] and [3], usually associated with this dialect, are realized in comparison to the alveolar $[\mathrm{s}]$ and $[\mathrm{z}]$, which appear to be more frequent in other dialects of Brazilian Portuguese.

The aforementioned studies provided very clarifying insights about the nature of the variation of post-vocalic $-\mathrm{s}$ in the Carioca dialect. The fact that these studies provide findings based on data recorded in the $1990 \mathrm{~s}$ led me to hypothesize that the linguistic patterns they report on were already in place in the 1970s and if so they were evidence of change in progress. With this in mind, the present paper was guided by the following research question: Being that [S] and [3] are the most frequent realizations of $-\mathrm{s}$ in the dialect of Rio de Janeiro, what are their most influential linguistic or nonlinguistic factors? The variants $[\mathrm{h}]$ and $[\varnothing]$ were also considered, but their incidence in the data was not statistically significant so that I could not give further explanations about their occurrence. In addition, the data used for the research were provided by collegelevel participants who took part in the NURC Project based in Rio de Janeiro, and so the realization of these variants was somehow constrained by the fact that I was analyzing standard urban speech since they are very socially stigmatized. Indeed, the fact that I did not consider data from people with less education was certainly one of the limitations of this study.

In any case, a series of VARBRUL analyses was carried out in order to answer the research question. I found that syllable type and age were the most influencing factor groups for the occurrence of [S] and [3] in our data. Among those factor groups, unstressed syllable environment and the younger age group (25-35 years old) represented the best conditioning factors for the phenomenon under investigation in this study. Although not conclusive, these findings make a significant contribution to sociolinguistic research, by providing new nuances to the study of post-vowel $-\mathrm{s}$ in Brazilian Portuguese, especially in the dialect of the city of Rio de Janeiro. 


\section{REFERENCES}

ACKERLIND, S. R.; JONES-KELLOGG, R. (2011). Portuguese: a reference manual. Austin, TX: University of Texas Press, (2000). 366p.

GRYNER, H. ; MACEDO, A. V. T. A pronúncia do-s pós vocálico na região de Cordeiro [Pronunciation of post-vocalic -s in the Cordeiro region]. In: Maria C. MOLLICA, M. C.; MARTELOTTA, M. E. (2000). Análises linguísticas: A contribuiçãoo de Alzira Macedo [Linguistic analyses: Alzira Macedo's contribution]. Rio de Janeiro: UFRJ. p 26-51.

GUY, G. R. (1981). Linguistic variation in Brazilian Portuguese: Aspects of the phonology, syntax, and language history. 1981. 391p. (Ph. D. Dissertation) - University of Pennsylvania, Philadelphia.

LABOV, W. (1972). Sociolinguistic patterns. Philadelphia: University of Pennsylvania Press, 362p.

LOPEZ, B. S. (1979). The sound pattern of Brazilian Portuguese (Cariocan dialect). 265p. (Ph. D. Dissertation) University of California, Los Angeles. 1979

NASCENTES, A. (1953). O linguajar carioca [The Carioca dialect]. 2nd ed. Rio de Janeiro: Organização Simões, 217p.

PERINI, M. A. (2002). Modern Portuguese: A reference grammar. New Haven, CT: Yale University, 592 p.

REIS, I. (1992). Retraction in Cariocan Portuguese. Kansas Working Papers in Linguistics, Kansas, v. 17 , p. $25-53$.

SCHERRE, M. M. P.; MACEDO, A. V. T. Restrições fonético-fonológicas e lexicais: O -s pósvocálico no Rio de Janeiro [Phonetic, phonologic, and lexical restrictions: Post-vocalic $-\mathrm{s}$ in Rio de Janeiro]. In: MOLliCA, M. C.; MARTELOTTA, M. E. (eds.) (2000). Análises linguísticas: A contribuiçãoo de Alzira Macedo [Linguistic analyses: Alzira Macedo's contribution]. Rio de Janeiro: UFRJ, p. 52-64.

SILVA, T. C. Fonética e fonologia do português: roteiro de estudos e guia de exercícios [Phonetics and Phonology of Portuguese: Study guide and exercises]. São Paulo, SP: Contexto, 1998. p. 254. 